Existential and Phenomenological Conceptions of the Relationship Between Philosophy and Theology

Renxiang Liu*

\title{
Sartre's Godless Theology: Dualist Monism and Its Temporal Dimensions
}

https://doi.org/10.1515/opth-2019-0017

Received April 28, 2019; accepted June 17, 2019

\begin{abstract}
My task in this paper is to study Sartre's ontology as a godless theology. The urgency of defending freedom and responsibility in the face of determinism called for an overarching first principle, a role that God used to play. I first show why such a principle is important and how Sartre filled the void that God had left with a solipsist consciousness. Then I characterize Sartre's ontology of this consciousness as a "dualist monism", explaining how it supports his radical conception of freedom. Then, by assessing Sartre's dualist monism through a theological lens, I disclose an inconsistency in his thought concerning the idea that the in-itself is a deterministic plenitude, which presumes a theos different from consciousness and hence threatens monism. Finally I argue that his inconsistency originates from the finitude of Sartre's first principle and analyze this finitude by examining the modes of temporality it implies. The entire trajectory problematizes the practice of theo-logy, the idea that a theos stands at the origin of the "logic" (organization or intelligibility) of everything such that all must be conceived under the logos of the theos. While Sartre forcefully criticized the theology of the infinite, his was nonetheless a theology of finitude.
\end{abstract}

Keywords: Jean-Paul Sartre; Dualist monism; Godless theology; Freedom; Ontology; Finitude

\section{Radical freedom}

In most introductory works, Jean-Paul Sartre is depicted as having endorsed a radical concept of freedom early in his career (that is, before writing Question de méthode [1957]): he seemed to contend that "freedom is without limits" and that "there are no degrees of freedom". ${ }^{1}$ This is not a total misinterpretation, as Sartre's own words corroborated it. For example, in Being and Nothingness he famously claimed that "we are condemned to freedom," and this applies even to a prisoner. ${ }^{2}$ Such a freedom seems indifferent to the varieties of life-situations and, consequently, is not very informative on the socio-political level. If everyone were free without qualification, it would be pointless to promote freedom.

Upon a closer look, however, this charge is beside the point. Sartre distinguishes "to obtain what one has wished" from "by oneself to determine oneself to wish". ${ }^{3}$ While we usually understand freedom as the former, which obviously comes in degrees, Sartrean freedom means only the latter: "success is not important to freedom." 4 Thus precluding any external limitation from compromising it, Sartrean freedom turns out to be absolute.

\footnotetext{
1 Bernasconi, How to Read Sartre, 47, 51.

2 Sartre, Being and Nothingness, 622-623.

3 Ibid., 621.

4 Ibid.
}

*Corresponding author: Renxiang Liu, McGill University, Montreal, Canada; E-mail: renxiang.liu@mail.mcgill.ca 
So why would Sartre need this absolute concept of freedom? In Being and Nothingness it is inextricably linked with responsibility, since responsibility has no place in a completely deterministic world. As Paul Ricœur noted, I have to be the "author" of my acts so as to be responsible for them. ${ }^{5}$ If every act of mine were causally determined by things other than me, I would not be responsible for any of them. The significance of Sartrean freedom thus consists in its ethical appeal: if Sartre can show that a sense of freedom prevails over even the severest limitation, one can no longer exempt oneself from moral responsibility by referring to causal determination-be it physical, psychological or social-as many did in Vichy France.

This whole problematics reminds us of Augustine's attempt to establish free will in the face of Hellenistic rationalism so as to accommodate the notion of guilt. It also recurred in Kant's practical philosophy: while the phenomenal world is dominated by causal necessity, practical reason posits freedom in the noumenon. Kant said that he "had to deny knowledge in order to make room for faith." 6 The common practice to establish freedom, therefore, entails clearing up, within the plenum of causal and material determination, a space of nullity where personal decision makes a difference.

Sartre's ontology was no exception. This is evident from the apparent dualism in Being and Nothingness between the in-itself and the for-itself: while the in-itself constitutes "the plenitude of being and positivity", 7 the for-itself arises only as a negation of, i.e., incoincidence with, the in-itself. ${ }^{8}$ Because being, ${ }^{9}$ as a plenitude, is determined by causal necessity, the site of freedom cannot be within being, but in a negation of being, i.e. in "nothingness" ${ }^{10}$ Thus understood, the whole book of Being and Nothingness is about how an space of nullity is cleared up, so that freedom and responsibility can make sense.

Of course there are approaches to establishing freedom other than Sartre's (rather traditional) move of clearing up a space of nullity. Michel Henry, for example, saw freedom as not only in the negation of being, but more fundamentally in a "softer" immanent being that predates the negation. ${ }^{11}$ Such a being Henry called "life". Determinism was never so threatening to Henry as to Sartre, since for Henry it does not pervade the totality of being. Consequently, there was no need for freedom to retreat into a certain nullity.

On a second note, it comes as no surprise that ethico-political freedom was less important in Henry's philosophy than in Sartre's. Freedom for Henry was primarily a bliss, not an urgency. This brief comparison shows that even Sartre's "theoretical" philosophy, i.e., his "phenomenological ontology" (the subtitle of Being and Nothingness), was very likely motivated by ethico-political concerns to begin with. The current paper will hopefully show that some of Sartre's theoretical inclinations in Being and Nothingness can hardly be understood on the grounds of ontology alone, but is better explained with an urgency to establish human freedom in the face of determinism.

\section{Dualist monism}

Sartre's notion of freedom has been controversial, not only because of its practical implications, but also because it is theoretically problematic. For example, if the tenor of his ontology were really the dualism just mentioned between the in-itself and the for-itself, it seems that freedom, though important, might be an illusion. For example, Sebastian Gardner argues that "it remains entirely possible that all of Sartre's theory of nothingness, freedom, the mode of being of the for-itself, etc., is simply the expression of a systematic illusion: it is possible that Sartrean belief in the reality of everything over and above being-in-

5 Ricœur, “The Concept of Responsibility”, 14.

6 Kant, Critique of Pure Reason, B xxx.

7 Sartre, Being and Nothingness, 43.

8 Ibid., 100. Hence Sartre's famous formula: "We have to deal with human reality as a being which is what it is not and which is not what it is." (Ibid.) Here "what it is" refers to the human being considered as an in-itself, as a mere thing.

9 Here I am equating "being" with "being in-itself”. The two are not always synonymous in Being and Nothingness, as Sartre sometimes conceives "being" as including both the in-itself and the for-itself. However, since he denies the for-itself any independent and separate being, the term "being” usually refers to the in-itself alone, except in the Conclusion of Being and Nothingness.

10 We will see later in this paper how this negation is possible at all.

11 Henry, The Essence of Manifestation, 70. 
itself-everything which his ontology of the for-itself comprehends-is empty, and that in reality there is nothing but being-in-itself." ${ }^{12}$ After all, if our acts were completely determined at the level of the in-itself, a level independent from whatever happens at the level of the for-itself, ${ }^{13}$ then freedom (belonging only to the latter) would become superfluous. A freedom that does not guarantee us the opportunity of making a difference to being-in-itself (either to our own bodies or to world situations at large) hardly has any practical significance that Sartre needed.

I suggest this line of objection in order to expose a deeper problem, a problem that indeed haunts every ontology. If we adopt a fundamental dualism about beings, then the communication between the two sides becomes philosophically unaccountable. ${ }^{14}$ If, however, we are thus tempted into a monism, in which one side is reduced to the other, then we are unable to answer the question why the phenomenal duality between the two, which has (wrongly) suggested a dualism, should arise at all.

Take for example the dyad pivotal in Sartre's philosophy: (a) one's free consciousness and (b) factical limits one encounters. In a fundamental dualism, we are unable to show what happens when a free consciousness encounters a factical limit. In a monism, either we reduce facticity to freedom, hence fail to explain why there appears to be limits to freedom, or we reduce freedom to facticity, hence fail to explain why there appears to be freedom despite all the limits. It seems that a simplistic ontological model, one that reduces the vicissitude of beings to certain static grounding domain(s), is bound to fail, be it dualist or monist. ${ }^{15}$

Faced with the dilemma between dualism and monism, Sartre made an ingenious move. Instead of construing the limits as extrinsic to the free consciousness, he made them intrinsic ones. Sartre writes that "it is [...] our freedom which constitutes the limits which it will subsequently encounter."16 In other words, the limits are imposed by free consciousness on itself, and indeed for its own sake.

How to understand this? Let us first consider what it is like for a freedom to be without limits. Though this freedom may access any choice, it finds no reason for preferring any particular choice to the rest; the moment it prioritizes a choice over others, freedom becomes limited by the particularity of the choice. Take the example of the souls in Plato's Republic (an example Sartre himself made in Being and Nothingness) ${ }^{17}$ : a soul may choose to become an Athenian, a Spartan, or an Egyptian etc., but this "absolute" freedom to choose what one is ends up abstract and empty until the soul actually chooses to be (for example) an Egyptian. Once this happens, however, there are limits that necessarily follow. To name one limit, the Egyptian that the soul has become would stand a very small chance of meeting Plato in person.

As the example shows, begetting factical limits is a precondition of concrete freedom. Freedom itself demands limits. In this way, there is no longer a need to reconcile between two sides that are separate in the first place. We start from a monist principle (freedom), but this principle comprises a moment of selfdisintegration, so that it has to invite its other. ${ }^{18}$ We are then able to explain why there appears to be a duality between freedom and facticity.

12 Gardner, "Sartre, Schelling, and Onto-Theology", 261.

13 Sartre, Being and Nothingness, 787.

14 It may be argued that philosophy can nevertheless give a negative account of the communication between the two sides, i.e. it can give reasons why we cannot comprehend the communication. This may take the form of a weak claim or a strong claim. A weak claim is that the communication is incomprehensible within a certain explanatory framework, e.g. causality. But the claim of this "regional" incomprehensibility presupposes an underlying comprehensibility, usually within an alternative explanatory framework (e.g. phenomenological constitution), which, if articulated, would undermine said dualism: now the two sides can be grounded in one framework, and so the dualism here is not a fundamental one. A strong claim is that the communication is absolutely incomprehensible to us, whatever explanatory framework we adopt. But philosophically it is not very informative to claim on the one hand that there is something and to deny altogether its comprehensibility on the other hand-though I am aware that several philosophers have done so.

15 Early in his career Sartre already showed, under a slightly different problematics, that monism in the form of either realism or idealism is bound to fail. See Sartre, "Intentionality", 4.

16 Sartre, Being and Nothingness, 620.

17 Ibid., 132.

18 In this paper, a non-capitalized "other" of something means quite generally what is not the thing itself. Capitalized "Other" means other people. This is in conformity with Barnes' rendering in her English translation of Being and Nothingness. 
Thus construed, facticity is, only because of the demand of freedom to become more concrete, and in this way it is derivative of the free consciousness. It remains consciousness which encounters facticity and which continues to be its ontological basis. Nothing lies totally outside it. Sartre once claimed that "it is impossible to grasp facticity in its brute nudity", ${ }^{19}$ meaning that facticity does not stand opposite consciousness as if independent but rather is a moment of consciousness itself and is always shaped by consciousness. This does not mean that facticity is illusory; it is real, but nonetheless subordinate.

There is yet another way to understand Sartre's ontology, one that is more closely linked to the theme of theology. It concerns the curious concept "in-itself-for-itself" in Being and Nothingness. Sartre characterizes it as value, ${ }^{20}$ perfect being, ${ }^{21}$ the absolute, ${ }^{22}$ and, above all, the "Man-God" ${ }^{23}$ The in-itself-for-itself does not exist as part of reality, but is non-thematically presumed by consciousness (the for-itself) as a haunting "normative existence". ${ }^{24}$ The reason why Sartre has to posit the in-itself-for-itself is this. Recall that the upsurge of the for-itself is characterized as a negation of the in-itself, i.e., a movement in which the foritself dis-identifies with the in-itself, disclosing itself to be "what it is not" and to be "not what it is". ${ }^{25}$ Now, one precondition of this nihilation, Sartre says, is a "lack of being" on the part of the for-itself ${ }^{26}$, for otherwise the for-itself would not have to bother with the in-itself at all. (Here again we meet the abstract freedom detached from the factical world.) Specifically, this lack concerns the fact that the for-itself is not the foundation of its own being. ${ }^{27}$

If any lack can be defined with respect to (a) what lacks and (b) what is lacked, i.e., what (a) desires to be but in fact cannot, then it is clear in the current context that (a) is the for-itself. On the other hand, if the for-itself desires to be its own foundation but in fact cannot become so, then (b) would be an ideal being that is the foundation of its own being. ${ }^{28}$ That ideal being is exactly what Sartre calls the in-itself-foritself. Its name suggests (a) that it is inextricably tied to the lack, to the impossible desire of the for-itself to become the foundation of its own being and (b) that the way for the for-itself to (ideally) become the foundation of its own being is to beget a certain characteristic of the in-itself. That certain characteristic cannot be the utter contingency of the in-itself, both because the for-itself, too, is contingent, and because a contingent being, by definition, cannot be the foundation of its own being. What is it then? I suggest that it is the identity-or total coincidence-with itself, which is characteristic of the in-itself. The for-itself is defined as not this self-identity (which is why it is free), but as such it is prohibited in principle from being a foundation of its own being. Nevertheless, it strives to be that foundation, and the ideal being haunting (one may say motivating) this pursuit is the in-itself-for-itself.

Sartre's characterization of the in-itself-for-itself corroborates my interpretation of his ontology as a dualist monism, for the following reasons. First, when Sartre introduces the notion of the "lack of being", he emphasizes that this lack is not because an external being has expelled or removed something from the for-itself. Rather, the lack is a problem intrinsic to the for-itself, such that it is equivalent to the problem of transcendence, i.e., of a cogito having to "refer outside itself". ${ }^{29}$ Second, Sartre argues that "lack can come

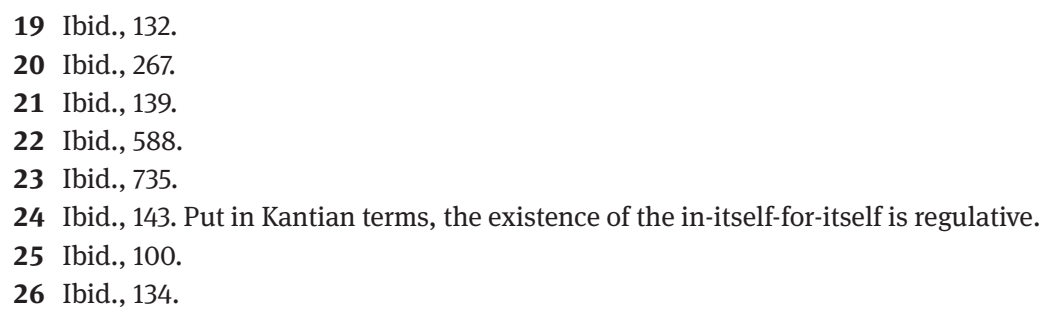
contingent and hence not founded at all. The for-itself, by contrast, is the foundation of its own nothingness, but not the foundation of its own being. This means that the constant movement of nihilation (meaning-making) unique to the for-itself accounts for its persistence in time. This comes in accordance with Sartre's move to abandon the metaphysics of substance, at least when it comes to the for-itself, and to replace the inert identity of the substance with a constant movement, a dynamic identity despite differences so to speak. However, that movement cannot account for the advent of the for-itself in the first place. In order to found its own being, i.e. its own advent, the for-itself would have to become an in-itself-for-itself-a causa sui in the traditional sense-which the for-itself can never accomplish but to which it perpetually strives.

28 Ibid., 139.

29 Ibid., 134. 
into being only through lack; the in-itself can not be the occasion of lack in the in-itself." ${ }^{30}$ In other words, were there only being-in-itself, the lack would not emerge at all; only the for-itself is capable of introducing the lack. Third, the relation of the in-itself-for-itself to the for-itself is "a total immanence which is achieved in total transcendence," ${ }^{31}$ so, at bottom, the for-itself's transcendence towards the in-itself-for-itself originates from, and remains grounded in, its own immanence. Fourth, the ideal that the for-itself strives towards, i.e., the in-itself-for-itself, is depicted in a sense of in-dependence and self-sufficiency: it is "a consciousness which would be the foundation of its own being-in-itself by the pure consciousness which it would have of itself." ${ }^{32}$ At the end of the day, the engagement with the brute in-itself is only instrumental, in the sense (a) that it serves only the desire of the for-itself to found its own being and that (b) were that desire fulfilled-in fact it cannot be-the aim is again to be "pure", to be purged of the contingency of the in-itself.

In summary, Sartre's ontology, despite its dualist tonality, is essentially monist. This is why I term it a "dualist monism". ${ }^{33}$

\section{Godless theology}

Sartre's ontology gives us the image of a free consciousness that, for the sake of concrete freedom, must be "caught in its own snare." ${ }^{34}$ Now, I would like to view this dualist monism through a theological lens. The aim is to make evident the price for Sartre of being a monist, and an inconsistent one at that. ${ }^{35}$

Upon first look, Sartre's ontology could not be more distant from a theology. Not only did he focus almost exclusively on "human reality" instead of the God-human relation; when he actually mentioned God, he usually sounded dismissive. In fact, he did not even need to argue vehemently as an "atheist" ${ }^{36}$ : most of the time he either (a) pointed out that the roles God played traditionally can in fact be fulfilled more properly by something originating from finite consciousness, ${ }^{37}$ or (b) showed that even if God exists, the structure of presence-to-itself, which is characteristic of the for-itself, would apply to God as well, and so God would necessarily be as finite and contingent as human beings ${ }^{38}$. In other words, God is either a misspelled name for certain aspects of human consciousness, or a being that, were it to exist, is essentially no greater than the human. Although Sartre did not go so far as to say that God is an illusion, it is doubtless that God is no longer an arch-principle in Sartre's ontology, but rather one of its outcomes. This hardly

30 Ibid., 136.

31 Ibid., 141.

32 Ibid., 723-724. My emphasis.

33 To be sure, there is another way to develop a dualist monism, i.e. to start from the material configuration of the world and see how it can develop into a free consciousness defying, or overcoming, material necessity. This can be found e.g. in Schelling in The Ages of the World, Hegel in Phenomenology of Spirit, or Bergson in Matter and Memory. But it was not an option for Sartre, both because his urgent aim was to make freedom a pervasive concept, and because he endorsed Husserl's phenomenological reduction and could no longer see material facts in a naïve way. For him, philosophy starts from questioning (Being and Nothingness, 35), and, because of this, anything we encounter has already been pigmented by this questioning. This explains Sartre's choice of the term "facticity"-it is always the facticity of a certain consciousness and is never impersonal.

34 Sartre, Sketch for a Theory of the Emotions, 52.

35 As mentioned earlier, my main contention is that Sartre's ontology is essentially monist, at least as it appears in his overall framework. I will argue later in this section, however, that his reduction of the in-itself to the facticity accompanying the foritself is incomplete, in the sense that a different theos inhabits the in-itself, so that the in-itself may be conceived as a deterministic plenitude.

36 In "Existentialism Is a Humanism", 53, Sartre pronounces that "existentialism is not so much an atheism in the sense that it would exhaust itself attempting to demonstrate the nonexistence of God; rather, it affirms that even if God were to exist, it would make no difference."

37 Those roles include, for example, an ideal "self" towards which "human reality surpasses itself" (Being and Nothingness, 139-140), which is exactly the in-itself-for-itself discussed at the end of Section 2; an extratemporal being which temporalizes instants that are themselves timeless (Ibid., 191); the source of a self-negation by which the Self encounters an Other (Ibid., 314315). In all these cases, Sartre argues that the notion of God depends on hypostatizing what is structurally intrinsic to finite consciousness into something transcendent to it.

38 For example, God is a contingent rather than necessary being (Ibid., 129); God "has the power to deny", and thus cannot be “a being wholly positive” (Ibid., 150-151); God has to "wait for the sugar to dissolve” (Ibid., 191). 
involved any specific effort from Sartre's side-living in a largely secular community in early 20th Century Paris, where it was religious belief, not unbelief, that would entail a deliberate personal commitment, Sartre was not really facilitating, but rather presuming, the "death of God".

But if God was not really an issue for Sartre, why did he mention God in his ontological work at all, and quite frequently at that ${ }^{39}$ The answer is already there in his treatment of God: he explained-or explained away - the notion of God, so that finite human consciousness may assume the ontological role God used to

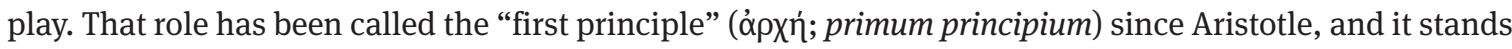
for the source of a unifying order, i.e., an overarching organization, of all beings; without a first principle, different beings would fall apart and come into contradiction.

While post-Hegelian philosophers were often skeptical about positing a first principle in the traditional, monotheist, and largely Christian sense, Sartre was not so unorthodox as he tended to advertise himself. His effort to establish a dualist monism showed that he wanted to dispense with God while maintaining the ontological structure that refers every being back to the first principle. His first principle, the free consciousness, underlies each being as its precondition: the meaning-making activity of consciousness is a torchlight that defines the content and boundary of the world. In short, Sartre's ontology implied ${ }^{40}$ a godless theology. There is a second but related sense in which Sartre's ontology implied a godless theology. He needed a first principle, not only to give organization to his "phenomenological" ontology, but also (as we said in Section 1) to clear up a space of freedom within the plenitude of the in-itself, the locus of determinism, so that there may be genuine responsibility. Compared to Kant's critical philosophy, the radicality of Sartre's dualist monism consists in his contention that the "space of freedom" in fact expands to the whole world. The world is not divided into a section of determination and one of freedom; rather, it is constituted by freedom at its heart. ${ }^{41}$ In this sense, freedom is pervasive and absolute, so that no room is left for excuses people make about transgressing due to external determinations. Even if I had a gun pointed at my head, I am free to choose whether to obey and whether to do the right thing-after all, the world (or at least $m y$ world $)^{42}$ originates from my free consciousness, and I am free to give meaning to that world, even if the way I give it meaning entails that I die, that I no longer dwell in that world.

It is illuminating to view this more "practical" orientation of Sartre's dualist monism through a theological lens, because here, as in traditional theology, the first principle is normative, i.e., it not only describes how things are, but more importantly defines how they ought to be. This "ought" is not at once ethical, though it is the precondition of any concrete ethics. ${ }^{43}$ An ethically "right" configuration of the

39 A brief search shows that the word "God" (capitalized) appears 77 times in Being and Nothingness and 29 times in "Existentialism Is a Humanism”, a lecture spanning only 37 pages in print.

40 I do not think that Sartre's ontology simply is a godless theology, considering that he distinguishes between ontology and metaphysics in the Conclusion of Being and Nothingness. The entire book is about ontology, the span of which is the same as transcendental philosophy in the Kantian sense, i.e. an inquiry into the preconditions of phenomena. Ontology points out those preconditions (e.g. the for-itself structure) without being entitled to answer why there are those preconditions at all. In other words, it takes for granted the advent of the transcendentals without bothering with their prehistory. The latter is left for metaphysical speculation, which can only be hypothetical and must conform to ontological findings. (Being and Nothingness, 788-790) To Sartre, what I express here under the name of "theology" would certainly belong to the side of metaphysics. That is why I only claim that his ontology implies a certain theology.

41 Gardner, “The Transcendental Dimensions of Sartre's Philosophy”, 49. In Sartre's metaphysical fiction, the upsurge of the for-itself at the heart of the in-itself is "a tiny nihilation [...] sufficient to cause a total upheaval to happen to the in-itself. This upheaval is the world." (Being and Nothingness, 786. My emphasis.) The in-itself is not yet a world; the concept of the world entails a self-disintegration that the for-itself alone can accommodate.

42 Here I do not go into the complexities of a solipsism that Sartre seems to endorse. It is beyond the span of this paper. In the case I make here, it does not matter whether the world is shared with others or is only mine. After all, it is my life which is at stake.

43 In a section called "Ethical Implications" at the end of Being and Nothingness Sartre touches on the relation between his ontology and articulated systems of morality, which he calls "the spirit of seriousness". He says, "the spirit of seriousness has two characteristics: it considers values as transcendent givens independent of human subjectivity, and it transfers the quality of 'desirable' from the ontological structure of things to their simple material constitution.” (Being and Nothingness, 796) In other words, morality is a confused way to express the ethical implications of ontology: hiding behind deterministic relations, it is "ashamed of itself" and "has obscured all its goals in order to free itself from anguish." (Ibid.) 
world (be it an individual act or a large-scale political institution) is first and foremost a configuration that observes the "ought", i.e., "makes sense" within the overall organization derived from the first principle. ${ }^{44}$

In Sartre's case, what is especially interesting is the relation between the first principle and the "ought" it defines. Instead of starting from a preconceived first principle in order to determine how things ought to be, he worked in the reverse direction. He started from an "ought" he posited apodictically, and that is everyone's responsibility for the entire world. He then searched for a first principle that, ideally, yields exactly that responsibility. This resonates with Kant's "practical” proof of the existence of God: God is, since otherwise the moral and social order would not hold. After the attack from F.H. Jacobi and Hegel, however, it was no longer an option for Sartre to endorse, like Kant, the first principle as a merely regulative idea. ${ }^{45}$ Sartre had to show instead that his first principle is constitutive in the Kantian sense. It was for this very reason that God was no longer a candidate.

What remained available was the Cartesian legacy of a solipsist consciousness. Sartre had to endorse it, though he made significant modifications to the Cartesian model. Briefly, Sartre criticized Descartes' model (and, according to him, Husserl's as well) for prioritizing reflective consciousness, which is based on a dualism between what reflects (cogito) and what is reflected on (world), hence leading to the dilemma between realism and idealism. He suggested that a pre-reflective consciousness precedes any reflection. This pre-reflective consciousness may serve as a first principle, because, as a relationality that precedes any of its terms, it constitutes both the ego and the world by giving them meaning. An ego or a worldly entity may be discovered only because it has always already been grasped in a pre-reflective meaning-making activity.

Though I think the pre-reflective consciousness is legitimate as a first principle, i.e., as a source of the ontological organization of beings, I want to argue that Sartre was not fully loyal to this picture.

At issue is his conception of the in-itself in Being and Nothingness. If the pre-reflective consciousness were the only first principle, as Sartre's dualist monism requires, it would follow that any organization of the in-itself must be derived from consciousness: left to itself, the in-itself would be a complete chaos devoid of concrete determination. ${ }^{46}$ But such is not always the case in Sartre's characterization of the in-itself. Though he mentions "the opacity of being-in-itself" ${ }^{47}$ suggesting that the in-itself lacks any intrinsic organization,

44 Spinoza's Ethics provides the most consistent example of this proto-ethical philosophy.

45 Jacobi (and also later Fichte) ridiculed Kant's attempt to "save” God as hypocritical, since according to Kant there is no way to establish God's existence with pure reason-in other words, God is, only because human beings need him for practical reasons. God thus construed is no longer the first principle; the first principle is rather the human subject that posits God for practical concerns. See Beiser, The Fate of Reason, 125.

Hegel further complicated the problem by criticizing Kant's ban of theology from pure reason. According to Hegel, this move of Kant (which later led to the exigency of reintroducing God through practical reason) was problematic, since Kant rendered finite human understanding something absolute, giving it a definite boundary which it can never exceed, thus obscuring the fact that finite understanding is only a transient and intermediary stage and thus may "pass over into" the infinite idea of God in speculative reason. See Hegel, Lectures on the Proofs of the Existence of God, 112-125; Lectures on the Philosophy of Religion, 105. Although in Being and Nothingness Sartre made frequent references to Hegel, it shall turn out in this paper that his position, especially his "dualist monism", was closer to that of Fichte. Like his predecessors Husserl and Heidegger, Sartre never failed to acknowledge the finitude of "human reality", his translation of Heideggerian Dasein. Hegel's reconciliation between the finite and the infinite would have sounded to Sartre as blatantly mystifying.

46 This idea may be exemplified either methodologically or ontologically. Husserl's talk of an "annihilation of the world" [Weltvernichtung] in Ideas I suggests a methodological "parenthesizing" of the world of things [Dingwelt] that, rather than doubting the existence of the things (a common misreading of Husserl), questions how they are given to consciousness as significant and meaningful. (Husserl, Ideas Pertaining to a Pure Phenomenology and to a Phenomenological Philosophy, First Book, 60-62; 109-110) Heidegger, on the other hand, gives an ontological account of how determinate meaning emerges from a primordial forgetfulness, or (in his later works) "nothing” [Nichts], or an undifferentiated "Earth" [Erde]. Both approaches imply that we do not take things in the world for granted, but rather turn toward their being (instead of non-being) as well as their intelligibility with wonder. Hence the "chaos" I put here is figurative: it does not signify a real chaos where every part of the in-itself has been examined and found to be chaotic; rather, it signifies an indeterminacy before any concrete determination, like it does in Greek myths.

47 Sartre, Being and Nothingness, 28. 
he says elsewhere (a) that it "has no need of" the for-itself ${ }^{48}$; (b) that it is "absolute plenitude and entire positivity", in other words "the totality of the real" ${ }^{49}$; (c) that it is constituted by "causal series". ${ }^{50}$

While (a) most obviously contradicts with the idea that the for-itself (consciousness) is the only first principle, (b) and (c) tell us more about Sartre's reason behind. Let us start with (c). We have seen in Section 1 that Sartre's ontology is oriented towards defending freedom and responsibility in the face of determinism. This presumes that causal necessity predominates the in-itself. But isn't causality also an organizationand, more acutely, an organization that is not derived from consciousness? This is immediately reminiscent of Descartes' conception of causality as the organization of res extensa, and his idea that the first principle of res extens $a$ is not the cogito, but God..$^{51}$ In the same vein, we can argue that there is another first principle (a contradiction in terms) underlying Sartre's ontology, one that governs the in-itself and gives it an organization of causality. Due to (a), this first principle of the in-itself cannot be consciousness, but has to be something else. ${ }^{52}$ Of course Sartre would not admit it to be God himself, but the overarching character of causal determination with respect to the in-itself strongly suggests an implicit assumption of a rationalist, Spinozean God, as was characteristic of enlightenment thinkers. ${ }^{53}$

Now, (b) only makes things worse. The ideas "plenitude" and "totality" suggest that the in-itself is fully articulated. We can speak of a "totality" only when we are (at least in principle) clear about each of its components..$^{54}$ But to be fully articulated is to assume an organization that, again, predates the advent of consciousness. Moreover, the organization now extends to the entirety of the in-itself, so that nothing of the in-itself is exempt from the causal determination expressed in (c). Thus the first principle of the in-itself, which issues causal determination, turns out to be an absolute principle opposed to consciousness. In other words, in Sartre's godless theology we find more than one "theos", irreducible to each other. This is the moment of inconsistency in Sartre's overall dualist monism.

To name a more consistent alternative, Heidegger took causality as an "ontical" [ontische] problem, which can only be understood when referred back to its ontological [ontologische] precondition, i.e. bringingforth [Her-vor-bringen] and revealing [Entbergen] ${ }^{55}$ Translated into Sartrean terms, this means causality, too, is rooted in the meaning-making activity of consciousness. ${ }^{56}$ It is a fault of "naturalistic rationalism"

48 Ibid., 49.

49 Ibid., 48, 51.

50 Ibid., 58.

51 Descartes, Meditations, 35-36 (original Latin in Euvres des Descartes, ed. C. Adam and P. Tannery, Vol. VII) / 25-26 (John Cottingham's English translation).

52 Sartre insists, till the end of Being and Nothingness, that the in-itself has "ontological primacy" over the for-itself. (Being and Nothingness, 787) Contrary to Gardner's contention in "Sartre, Schelling, and onto-theology", 250, this is not a threat to our general characterization of Sartre's ontology as a dualist monism derived from consciousness; otherwise, as I argued earlier, freedom would be illusory. Gardner's characterization of Sartre's ontology as "Parmenidean" is derived from his almost exclusive attention to an opening section "Being-in-itself" (Being and Nothingness, 24-30) and a concluding section "In-itself and for-itself: metaphysical implications" (Ibid., 785-795), omitting what lies in between. Though his focus is well justified by an attempt to stress the ontological aspect of Sartre's philosophy, which is more than often neglected ("Sartre, Schelling, and ontotheology", 248), what Gardner himself neglects is precisely the point that such an ontology serves the defense of freedom and cannot be properly understood without considering the latter, which appears in between the two sections he selects. In fact, those two sections do not belong properly to ontology (the theme of Being and Nothingness), but to metaphysics (see footnote 40 above), and what Sartre suggests in them about the prehistory of the in-itself before the advent of the for-itself (hence the advent of the world) is at most fictional. It helps us see the inconsistency in Sartre's own ontology as well as what worried him (and we will shortly), but it makes no threat to the "phenomenological", which is governed by the dualist monism of consciousness. 53 Admittedly, many enlightenment thinkers, for example Pierre-Simon Laplace, were more or less atheists. But from an ontological view they also gave an overarching organization to the totality of beings, and therefore their doctrines perfectly instantiated what I call a "godless theology".

54 For example, we may speak of the totality of natural numbers, because there is a method to derive any natural number by starting with 0 and adding up 1's. In this way, though we are not clear about every natural number in fact, we are clear about every one of them in principle. Again, this "principle” implies an organization.

55 Heidegger, Being and Time, 234; Heidegger, “The Question Concerning Technology”, 6-23.

56 This is my gloss of late Heidegger's esoteric terminology, but there are evidences that he was also concerned with the making of meaning when discussing the ontological precondition of causality. For example in History of the Concept of Time, 219, he claims that causality is a deficient mode in which we encounter the meaningfulness of the world. 
to hypostatize what are brought-forth and revealed, to make them into rigid causal relations populating an impersonal world.$^{57}$ In this way, Heidegger denied any separate first principle to causal relations, giving them only a derivative status. Accordingly, he would never conceive the world as a "plenitude" or "totality", but an unarticulated emptiness or forgetfulness.

Is there a reason why Sartre has to be inconsistent in this regard? I suggest there is. Recall that the free consciousness, which Sartre wants to make the only first principle, is characterized ontologically as a negation of the in-itself. As a negation, it presupposes something that is to be negated, which can only be what Sartre calls the "entire positivity" of the in-itself. ${ }^{58}$ In other words, the organization of the in-itself is needed as a background against which the meaning-making activity of consciousness constantly emerges. ${ }^{59}$ But, as we have seen, the organization of the negated background undermines the dualist monism of consciousness, since it implies a first principle other than consciousness.

Furthermore, Sartre's search for this negated background is exemplified in his somewhat gratuitous claim that the free consciousness is "totally unjustifiable" and contingent ${ }^{60}$-gratuitous in the sense that there is a logical leap. It is true that, as a first principle, consciousness has no further recourse. It does not follow, however, that it must be overtly contingent. A first principle can be necessary instead, as we see in the traditional conception of God as a causa sui. Or it can be neither necessary nor contingent, as we see in Heidegger: Dasein, though not a causa sui, is not eo ipso contingent, because in its average everydayness it does not strive to ground itself at all.

Sartre dismisses the first option by arguing that, even for a causa sui, the structure of presence-toitself involved in that reflexive "sui" entails a self-disintegration, which results in its contingency just as we witness in human consciousness. ${ }^{61}$ The second seems to have never appeared to Sartre as an option. In the section on the contingency of the for-itself, he says that the for-itself has "only a factual necessity; that is, it is the foundation of its consciousness-of-being or existence, but on no account can it found its presence."62 In other words, consciousness can only found, i.e., make ontologically intelligible, its persistence as a constant meaning-making activity, but cannot found the advent of that activity. Consciousness is indeed a first principle in that it founds all other beings, but the fact that there is consciousness at all is still groundless.

The question I pose to Sartre is however this: why even try? The way he starts with something "contingent" and looks for ever deeper "foundations" reminds us of the cosmological proof of the existence of God. Both are based on the conviction that everything ought to be founded, and in both cases the argument leads us gradually to the first principle. Unfortunately, the only first principle that was available to Sartre, the solipsist consciousness, ends up still too contingent for him. After all, that consciousness is temporal and singularized, unlike the eternal and omnipresent God. Thus the retrograde chain in search of a foundation

57 Heidegger, Being and Time, 497; Heidegger, History of the Concept of Time, 166, 184, 223.

58 This confirms Sartre's aforementioned view that the in-itself "has no need of" the for-itself. He writes, "logically nothingness is subsequent to being since it is being, first posited, then denied.” (Being and Nothingness, 47)

59 Though Sartre seems to side with Hegel, Nietzsche, Heidegger and Merleau-Ponty (to name a few) on the priority of "the metaphysics of becoming" over "the metaphysics of being", i.e. the idea that there is no inertia simpliciter in metaphysics and that for something to stay the same it must constantly become itself, it turns out at the end of Being and Nothingness that, for Sartre, the metaphysics of becoming applies only to the for-itself. The in-itself, by contrast, is still characterized by the metaphysics of being-to wit, by the inertia of matter. (Ibid., 787) As such, the in-itself conforms to the traditional metaphysical model of substance, except that it is constantly negated by the for-itself. But, as I am trying to show here, a negated substance is nonetheless a substance. The deterministic principle is like a theos that must be repeatedly decapitated, and the urgency to decapitate it stands for a lack, "an impossible vertical surpassing which by its very non-existence conditions the flat movement of consciousness.” (Ibid., 789) This almost mystical metaphor of a motivating nullity reveals the Freudian legacy in Sartre. It comes as no surprise that Sartre's metaphysics can be illuminated from the negative theology of Kierkegaard or Karl Barth.

60 Ibid., 131-132. There Sartre writes that "[I] apprehend myself simultaneously as totally responsible for my being-inasmuch as I am its foundation-and yet as totally unjustifiable. [...] In so far as this for-itself as such could also not be, it has all the contingency of fact."

61 Ibid., 128, 789. Hence the claim that "God, if he exists, is contingent." (Ibid., 129)

62 Ibid., 133. 
must stop at the solipsist consciousness, but ought not to. The ideal of an absolute foundation is "always indicated and always impossible." 63

In my view, this aporia, though only dimly in sight, may have induced Sartre to look elsewhere for a further foundation, even if that founding should take the form of a negation. In a footnote dialoguing with Hegel, Sartre submits that "the for-itself remains non-essential and contingent in relation to the in-itself." ${ }^{4}$ It seems that he wants the in-itself to be the further ground of the for-itself, albeit a negated one. For the in-itself to be a firm ground, then, causal necessity has to be smuggled through the back door, though Sartre would never admit it wholeheartedly, given his overall commitment to the dualist monism of the free consciousness. At the end of the day, Sartre was not that far from traditional foundationalists, and that temporal, singularized "god" of his ontology, the free consciousness, cannot claim to be the only first principle, but eventually has to give way to, or at least feed on (by way of negation), another god, i.e., the god of what Heidegger calls "naturalist rationalism". ${ }^{65}$

\section{The temporality of a finite theos}

I have shown what the implications are for Sartre in adopting a "godless theology" where the theos (in his case the solipsist consciousness) is temporal, singularized-in a word, finite. Both temporality and singularity are crucial to the ontological account Being and Nothingness gives. The temporality of consciousness supports the basic structures of negation, presence-to-self, and projection, whereas the singularity of consciousness leads to Sartre's impressive characterization of the encounter with an Other. Here we only have space to deal with the former in order to deepen the critique in the previous section, though we must bear in mind that those two aspects are interdependent and equiprimordial.

Considering Sartre's dualist monism, there is a moment of self-disintegration that is rarely found in traditional ontologies. Sartre's first principle, the free consciousness, has to invite its other so as to become concrete (Section 2). Its identity has to beget difference in order to persist as an identity. Insofar as the other here is considered to be the in-itself, ${ }^{66}$ Sartre has a reason to proclaim that "we have to deal with human reality as a being which is what it is not and which is not what it is." ${ }^{\circ 7}$ In comparison, the traditional notion of God knows of no "other". God is simply what he is. ${ }^{68}$

However, this self-disintegration of the for-itself is not just a deficiency that makes it "less" than a perfect first principle such as God. Quite the contrary, self-disintegration is necessary for consciousness (a) to be a free consciousness and (b) to be a first principle by way of meaning-making. It is precisely under the problematics of temporality that Sartre elaborates on these implications of self-disintegration. After all, to be temporal means to disintegrate, to become an other eventually.

Let us start with (a). Section 1 has shown that Sartre's entire ontology is motivated by an urgency to let freedom and responsibility make sense in the face of determinism. Now, freedom has two elements: to be free from something, and to be free for something. Within Sartre's discussion of temporality, the formula would be: consciousness is free from its past and free for its future.

When considering freedom in the context of action, Sartre says that facticity consists of "my place, my body, my past, my position, [...] my fundamental relation to the Other." ${ }^{69}$ If facticity signifies the other

63 Ibid., 792.

64 Ibid., 145. My emphasis.

65 Gardner in “The Transcendental Dimension of Sartre’s Philosophy” (2010) claims that Sartre's philosophy features an "opposition [...] to philosophical naturalism" (49). This is very true, as we have shown in Section 1. Here, however, I want to add that Sartre can be an anti-naturalist only because he is a naturalist as regards the in-itself. A god to be fought against is not any less of a god.

66 Thus we are leaving aside cases where the other of consciousness is another person, i.e. another free consciousness.

67 Sartre, Being and Nothingness, 100.

68 To be sure, there are accounts of God in which God also posits his other, most significantly in Hegel's Lectures on the Philosophy of Religion, 417-489. But there God is understood as the absolute Spirit, which at bottom is humane. Thus it is no longer in line with traditional accounts of God as transcendent. See also Hegel, Aesthetics, Vol. I, 534-539.

69 Sartre, Being and Nothingness, 629. My emphasis. 
posited by consciousness, and if the past is a moment of facticity, it follows that consciousness encounters its past as an other, that the past embodies the in-itself insofar as its span is defined by the torchlight of consciousness. ${ }^{70}$ The past is what it is. Freedom, then, entails a departure from this in-itself past, so that consciousness is "not what it is", i.e., not totally convergent with its past. As Sartre says, "that heavy plenitude of being is behind me; there is an absolute distance which cuts it from me and makes it fall out of my reach, without contact, without connections." ${ }^{\prime 11}$ Since my consciousness is a self-disintegration, a negation of the it-itself, I am my past only in the mode of having been it. As an it-itself, my past is impotent, unable to determine what I will be. The fault of determinism consists precisely in short-circuiting the past with the future, so that the former, qua in-itself, determines the latter with full necessity and immediacy. By contrast, Sartre insists that the for-itself is "diasporatic". ${ }^{72}$ It hosts a radical break from the past, a break incompatible with the continuous and even flow of linear time, the time of determinism.

In what dimension of time, then, should we look for freedom? Sartre says, "in the past the world surrounds me, and I lose myself in the universal determinism; but I radically transcend my past toward the future to the same extent that I 'was it."'73 To be sure, this transcendence does not mean that one can arbitrarily change one's past. To manipulate the in-itself at will is something even the free consciousness has no freedom for. However, one can always "choose the meaning" of one's past. ${ }^{74}$ With this we are led to (b), i.e. the meaning-making activity. A clarification of it allows us to see what kind of freedom consciousness as a first principle enjoys, why freedom lies in the future, and why freedom and meaning-making necessitate a self-disintegration on the part of consciousness.

For Sartre, meaning is impossible without consciousness. ${ }^{75}$ Specifically, meaning arises from finality, ${ }^{76}$ i.e., "a result to be attained", which is unique to consciousness. ${ }^{77}$ However, a result to be attained does not yet exist. It is anticipated in a future, wide open, where the result may or may not be attained. When Sartre posits consciousness as the first principle on the grounds that consciousness makes meaning of every being, he means that each being is constituted according to the finality of consciousness, to what consciousness is about to attain. The example Sartre gives is climbing up a mountain: the rocks appear as easy-to-climb or difficult-to-climb only if consciousness posits a project to climb. To a consciousness that posits a different project, e.g., "the simple traveler who passes over this road and whose free project is a pure aesthetic ordering of the landscape, the crag is not revealed either as scalable or as not-scalable; it is manifested only as beautiful or ugly."78 All these meanings are thus derived from the project, or "end", of consciousness. ${ }^{79}$

We can now see in a temporal lens what freedom really means. The project provides an overarching framework in which alone everything acquires its meaning. But the project itself is never determined, either by one's past as in-itself, or by the in-itself world at large, for what is projected "does not yet exist"80_

70 Hence Sartre says, "there is not first a universal past which would later be particularized in concrete pasts"; "the past is the in-itself which I am"; "it is through the for-itself that the past in general can exist.” (Ibid., 165, 173, 199. My emphasis.) The past is thus not the in-itself pure and simple; it must be viewed within the overarching framework of dualist monism.

71 Ibid., 172.

72 Ibid., 195.

73 Ibid., 208.

74 Ibid., 131, 170.

75 Ibid., 25.

76 The word "finality" does not appear quite often in Being and Nothingness. However, in Sketch for a Theory of the Emotions, widely considered a prelude to Being and Nothingness, Sartre used the notion of "finality" to show that causal explanations of psychology missed the meaning of emotions because they prohibited any talk of finality. Sartre, Sketch for a Theory of the Emotions, 21-22.

77 Sartre, Being and Nothingness, 613.

78 Ibid., 627.

79 Thus construed, the Sartrean notion of finality is close to Aristotle's final cause, except that the Aristotelian final cause may apply to any being while Sartrean finality only applies to being-for-itself. A closer candidate may be Heidegger's “for-the-sakeof-which" [das Worumwillen] in Being and Time, though Heidegger's notion involves a re-appropriation of the past (tradition) that Sartre's does not, at least not explicitly.

80 Ibid., 614, 621. 
namely, it belongs to a radically open future. It is thus the openness of the future that permits freedom to consciousness, that allows consciousness to be a first principle through meaning-making.

It remains to be seen why consciousness has that power of separating, as it were, its in-itself past from its radically open future. From the perspective of linear time, this is simply incomprehensible. But we have to recall that, for Sartre, both the past and the future are mine; they are conceived within the framework of dualist monism. So, the secret is in consciousness itself, specifically in its self-disintegration.

In a section titled "The Future", Sartre says: "I project myself toward the future in order to merge there with that which I lack; that is, with that which if synthetically added to my present would make me be what I am." ${ }^{81}$ Here, he expresses the idea that consciousness suffers a lack at its heart. Its present, when considered as in-itself, does not exhaust its being; there is something more to "what I am". The lack can only be filled by a future self; "what I am" can be fully defined only with respect to "what I am going to be". Thus, for consciousness to make meaning and to constitute beings, it must always go beyond what it already is; it features a non-convergence with its past (I am my past in the mode of having been it) and a finality towards its future (I am defined by what I am not yet). ${ }^{82}$ The moment of negation, here expressed in "non-convergence" and "not yet", characterizes the self-disintegration of consciousness. Consciousness, in order to be a consciousness, must constantly become a new consciousness, whether or not it is qualitatively different from the "old" consciousness. ${ }^{83}$ For Sartre, this "newness" is more primordial than the newness of linear time: linear time "flows", only because consciousness hosts a perpetual movement of selfdisintegration. ${ }^{84}$

Now we see how Sartre gives the mortality (being-temporal) and finitude of consciousness a positive role. It is precisely the self-disintegration of consciousness that (a) makes consciousness free from the past for the future and (b) lets consciousness be a first principle by way of positing a project which "does not yet exist" and make meaning of everything according to that project. In this sense, human being enjoys a freedom and a meaningfulness that God, traditionally conceived, does not: God's consciousness would be self-identical, and its project would already exist (there is no distance between potentiality and actuality in God), and so the freedom and meaningfulness stemming from being-temporal would be unavailable to God. This includes, for example, radical changes in one's life course, wonder about or disappointment with what newly arises, and self-esteem in one's accomplishment within a limited lifespan.

Here a problem arises. In terms of its temporality, the self-disintegrating consciousness is dissymmetric: its past is absolutely fixed, while its future is absolutely not-yet fixed. As Sartre says, "if I can not re-enter into the past, it is not because some magical power puts it beyond my reach but because it is in-itself and because I am for-myself." ${ }^{85}$ The temporal abyss is between a fixed being that I was and a radical openness that I will be. Nevertheless, consciousness has to bridge the two, to let one "flow into" the other, despite their fundamental discontinuity and heterogeneity.

Is Sartrean consciousness really capable of this? If my project, the source of my meaning-making, simply arises from a future which is yet nothing, isn't my freedom-by which my consciousness posits the projectagain a most abstract one, just like the abstract freedom of the Platonic soul (Section 2)? Nothing of my past, of my life history or my social identities, is able to originally inform the positing of my project, for, in order to do so, my past would have to be appropriated under a ready-made project in the first place. Conceived as a fixed in-itself, the past can only be negated, i.e., taken up by a project alien to and independent of it,

81 Ibid., 184.

82 Thus Sartre's seemingly paradoxical claim: consciousness "drives us outside the instant toward that which it is in the mode of not being it." (Ibid., 147-148)

83 For to remain the same is just to repeatedly become the same consciousness. As I expressed in footnote 59 above, Sartre applies the metaphysics of becoming to the for-itself.

84 De Warren in Husserl and the Promise of Time, 201-205, once expressed a similar idea when discussing Husserl's "absolute flow of consciousness". Though I am indebted to his formulation of "self-differentiation", it is not very likely that Sartre was directly informed by Husserl's account of time-consciousness. For one thing, there is no evidence showing that Sartre had access to Husserl's Bernau Manuscripts on Time-Consciousness (1917/1918), which was not edited and published until 2001. For another, Husserl's mature account of self-differentiation is neither dissymmetric nor unidirectional as self-disintegration is in Sartre, which we will shortly see.

85 Sartre, Being and Nothingness, 173. 
but can never inform that project. The self-disintegration of consciousness is thus not only dissymmetric, but also unidirectional. As a first principle, consciousness finds itself again in a desert of radical openness, without being able to make any concrete choice; like the traditional God, it must create ex nihilo ${ }^{86}$

To be fair, Sartre can reply that one's particular ends are informed by an "original project", ${ }^{87}$ which, in turn, has always already been chosen. ${ }^{88}$ If the project has always already become concrete, it makes no sense to ask how exactly it becomes so. Consciousness does not first stand before a radical openness (hence emptiness) of the future so as then to make its choice. Accordingly, it is not a problem if its past can only be negated and cannot inform its choice originally.

This is very true. But isn't it precisely the temporality of this "always already" that Sartre's framework prohibits to address? For him, the past can be living (informative) or dead, but either way it is my past, it must have once been present to the meaning-making activity of my consciousness, for otherwise consciousness can no longer claim its priority as a first principle. ${ }^{89}$ By contrast, the "always already" of the original project is an immemorial past; to borrow Merleau-Ponty's term, it is "a past that has never been present." 90

Think of birth: it is a past of consciousness that has never been present to it, since consciousness is only possible thanks to this birth. All the particularities that come together with birth already prepare a landscape for the consciousness that is born into them, so that one may have a concrete original project. One is born in a certain country, as member of a certain cultural community, into a certain family, and within a certain historical era. These are more ancient than the one born into them: for an individual meaning-making consciousness, they have always already been part of its horizon. Moreover, they inform and constitute that consciousness, albeit never in a fully deterministic way. ${ }^{91}$ Jean-Louis Chrétien has termed this immemorial past "an excess that founds me, that sends me and destines me, and is known to me only obliquely, in the excess of being." 92 Thus freedom, characterized by the radical openness of the future, remains abstract unless enveloped and informed by such an immemorial past.

The reason why Sartre has to keep this immemorial yet informative past at bay is parallel to the reason why he has to render the in-itself an opaque plenitude. ${ }^{93}$ Both originate from his dualist monism. Due to the constitutive primacy Sartre gives to consciousness, he is not entitled to talk about the immemorial past thematically, since that would allow the past to exist independently of any appropriating consciousness and would push his philosophy dangerously close to determinism. Similarly, the it-itself is opaque unless penetrated by a meaning-making consciousness and appropriated as the latter's facticity. The paradox at issue is that Sartre both needs these ideas to give a complete account of consciousness and excludes them due to his dualist monism of consciousness. The result, as we have seen at the end of Section 3, is that consciousness turns out to be starkly contingent: in search of a ground, yet groundless in principle. Similarly, the finding of this section may be summarized thus: the free consciousness, in order to be concrete, is in search of an immemorial past that informs its choices, yet the constitutive primacy of the future-oriented "project" of consciousness precludes that immemorial past in principle.

86 Admittedly, this creation concerns only the meaning of things, not things themselves. But the point here is that neither version of the first principle is originally informed by a past.

87 Ibid., 583, 597.

88 Sartre sometimes equates this original project with Heidegger's notion of being-in-the-world. (Ibid., 589) As such, the original project concerns one's fundamental being, or what kind of person one is: it is "a certain choice which the for-itself makes of itself in the presence of the problem of being.” (Ibid., 587) Rather than being made till some point in one's life, the choice is one's life. When it gets problematized, one is already living, i.e. one has already made the choice. The discovery of the original project can only be post facto.

89 Ibid., 641-642.

90 Merleau-Ponty, Phenomenology of Perception, 252.

91 Romano, Event and Time, 213-218; Event and World, 69-82. Romano there also expresses the idea that birth means that my meaning-making is ultimately rooted in being-with-Others. The link between the immemorial past and Others can only be treated in another paper.

92 Chrétien, The Unforgettable and the Unhoped for, 16.

93 Sartre, Being and Nothingness, 28. 


\section{Conclusion: The limit of theo-logy}

My effort so far has been to show how Sartre's ontology, despite its atheist guise, remains a theology which refers the organization of every being back to a first principle-except that his first principle is the solipsist consciousness: finite, temporal, and singularized.

Here, theology is understood as theo-logy, the idea that a theos stands at the origin of the "logic" (organization or intelligibility) of everything, such that all must be conceived under the logos of the theos. This orientation is ontological and applies across different religious commitments, or lack thereof. I think it is close to what Sebastian Gardner calls "onto-theology": "a philosophical position that regards the intelligibility of our and the world's being as bound up metaphysically with the concept of a highest being," 94 though my notion is arguably broader than Gardner's in that (a) I do not identify the theos exclusively with a theistic God and (b) I do not necessarily conceive this theos as "having at least some attributes of personality, mind, or subjectivity." ${ }^{95}$

In traditional theo-logy, the theos is infinite and eternal. Its logos is therefore all-encompassing, which leads to a totalization of Being into one singular organization. The culmination of it was the rationalistic theo-logy of the Enlightenment, where, with the advance of mathematized natural science, the singular organization was found in deterministic causality. The generation after Kant, notably F. H. Jacobi, has found that the most consistent version of rational theology is Spinozism, a perfect monism in which all is determined. ${ }^{96}$ Human freedom, then, becomes trivial, if not eliminated, under such a view.

Sartre was well aware of the dead-end of traditional theo-logy, and in his own ontology he therefore tried to set up the free consciousness as the first principle-a first principle that is necessarily finite and temporal. However, the problem of theo-logy most probably did not appear to him as a problem of theology, since his alternative was still a theo-logy, albeit a godless one. Now it is consciousness that gives organization to beings by constituting their meaning. Moreover, Sartre's account of the in-itself in an oblique way threatens to duplicate traditional theo-logy, especially its deterministic view of beings, setting it as what the positive part of his ontology must react against.

I am not claiming that the deterministic picture is fully articulated in Sartre's account of the in-itself (if so, it would invalidate the monism of free consciousness). I am only claiming that an ambiguity underlies Sartre's godless theo-logy. When the first principle is finite and temporal, the ontological map that grows from it necessarily leaves out something, which is turned into the posited "other" in dualist monism, into a formless shadow that can never be brought to light-after all, the light itself is finite and incapable of containing its other. This ontological residue, then, continues to haunt Sartre, and all he can do is to allude to it without explicitly crossing the boundary dictated by the finite first principle. Just as he alludes to the in-itself with the notion of "coefficient of adversity" ${ }^{27}$, he alludes to the immemorial past with the philosophical fiction of the in-itself attempting to "found" itself and thus becoming "a memory of being" in the for-itself. ${ }^{98}$

On top of all these, it is quite telling what life is like in his view: totally responsible, yet totally unjustifiable. ${ }^{99}$ The whole world weighs on one's shoulders, ${ }^{100}$ while the one has no firm ground to stand on. After all, finitude is not a self-sufficient concept, but always presumes that which limits it. When a

94 Gardner, “Sartre, Schelling, and Onto-Theology”, 267 (endnote 14).

95 Ibid.

96 di Giovanni, Freedom and Religion in Kant and His Immediate Successors, 143-145.

97 In Sartre's example of trying to climb up a mountain, the coefficient of adversity refers to the fact that the mountain "responds" differently depending on one's project to engage with it. (Being and Nothingness, 628) His central claim is that we cannot isolate the coefficient of adversity a thing gives as if it were independent of projects; rather, even to study it "neutrally" is a particular project, and in any case it is always a "co-efficient". We can only fathom it via different projects, but never without projects.

98 Ibid., 133.

99 Ibid., 131.

100 Ibid., 707. 
godless theo-logy renders something finite an absolute principle, the "lack" we have seen in Section 2 strikes back.

Of course, there have been alternative traditions in theology which did not give a totalizing picture of beings based either on an infinite theos or a finite one. In my view, however, those should more appropriately be called "religious thought" rather than "theology", as they do not attempt to derive all beings from God in a definite, "logical" way. We have to distinguish between (a) what the name "theology" entails and (b) historical practices under the banner of "theology". The name "theo-logy" applies only to the former.

If a theo-logy of infinitude leads to lifeless determinism, and if a theo-logy of finitude leads to an uncanny and restless life, what instead would make room for a blessed life, concretely free, yet not overburdened by unjustifiability? My view is that theo-logy, as I characterize it, must be overcome by a theos that does not exhaust the world in its logos. Instead of excluding its other, be that human freedom (hence the possibility to falter) or nature (hence the risk of bondage), it must be able to contain its other without thereby being overwhelmed by it. ${ }^{101}$ The world must stand mistakes and unfreedom, but in such a way that they are only intermediary and transient. Whether we characterize that "theos beyond theo-logy" as finite or infinite, however, remains an open question.

Though my discussion in this paper cannot say much about the general relation between philosophy and theology, it helps us see philosophy's long-lasting entanglement with what I have called "theo-logy". To philosophize means to try to give organization and intelligibility to beings, which is why philosophy frequently ends up giving theo-logical-that is, totalizing-accounts. But philosophy is arguably more than that, since, by articulating certain theo-logies, it is able to see their limits and to overcome them, though not without the risk of running into another theo-logy. Sartre's struggle with determinism is a case in point. Figuratively, one can say that theo-logies are the steps philosophy has to take, but philosophy itself cannot be identified with any definite step; it is a restless movement.

\section{References}

Beiser, Frederick C. The Fate of Reason: German Philosophy from Kant to Fichte. Cambridge, MA: Harvard University Press, 1987.

Bernasconi, Robert. How to Read Sartre. New York: W.W. Norton \& Company, 2006.

Chrétien, Jean-Louis. The Unforgettable and the Unhoped for. Translated by Jeffrey Bloechl. New York: Fordham University Press, 2002.

Descartes, René. Meditations on First Philosophy. Translated by John Cottingham. Cambridge: Cambridge University Press, 1996.

Gardner, Sebastian. "Sartre, Schelling, and Onto-Theology." Religious Studies 42, no. 3 (2006): 247-71.

Gardner, Sebastian. "The Transcendental Dimension of Sartre's Philosophy.” In Reading Sartre: On Phenomenology and Existentialism, edited by Jonathan Webber, 48-71. London: Routledge, 2010.

101 In fact, this was the orientation of Hegel, who has always overshadowed Sartre. Hegel's objection to theo-logy arose in the pantheism debate between rational theologians like Moses Mendelssohn and fideists like F.H. Jacobi. While the former wanted to "prove" God with conceptual understanding alone, the latter discredited conceptual understanding and proposed instead an intuitive relation to God. Hegel pointed out that both parties fell prey to the dichotomy between theo-logy and irrational belief, which is an aftermath of Spinozean monism. He suggested, instead, that speculative reason is capable of containing, rather than excluding, its other. The culmination of this reason, then, is not in theo-logy as a monist world-view-Sartre's dualist monism being a case in point-but in religion, i.e. the community between human consciousness and God. This community is able to contain evil, so that there can be concrete freedom without total groundlessness. As di Giovanni writes in "Spinoza's Persistent Challenge" (unpublished), "Hegel had cut through this ambiguity [of monism], for in his metaphysics of becoming the Absolute-a veritable Abgrund der Vernunft which in Hegel's Logic is superceded by the end of the Second Book-gave place to Spirit. The knowledge-knowing-itself of which the 'absolute Idea' is only a reflective representation is to be found realized in the works of Spirit, that is, in the sciences and the cultures of which in the Phenomenology Hegel gave a historically based accountfictional in many ways, but not mythological. The Logic itself is the ultimate reflective product of a philosophically enlightened culture. The true God is to be found only in a spiritually motivated community. Contrary to both Fichte and Schelling, nature is for Hegel neither an idea nor anything in itself divine, but simply the past of Spirit, the source of Spirit's finitude with which it is Spirit's work to find reconciliation. With this, however, we enter the domain of religion." 
di Giovanni, George. Freedom and Religion in Kant and His Immediate Successors: The Vocation of Humankind, 1774-1800. Cambridge: Cambridge University Press, 2005.

di Giovanni, George. “Spinoza’s Persistent Challenge: An Essay in Post-1800 German Idealism.” (unpublished book-length manuscript), 2019.

Hegel, Georg Wilhelm Friedrich. Aesthetics: Lectures on Fine Art. Translated by T. M. Knox. Vol. I, Oxford: Clarendon Press, 1975.

Hegel, Georg Wilhelm Friedrich. Lectures on the Philosophy of Religion. Translated by R. F. Brown, Peter C. Hodgson and J. M. Stewart. Berkeley, CA: University of California Press, 1988.

Hegel, Georg Wilhelm Friedrich. Lectures on the Proofs of the Existence of God. Translated by Peter C. Hodgson. Oxford: Oxford University Press, 2007.

Heidegger, Martin. Being and Time. Translated by John Macquarrie and Edward Robinson. New York: Harper\&Row, 1962.

Heidegger, Martin. “The Question Concerning Technology.” Translated by William Lovitt. In The Question Concerning Technology and Other Essays, 3-35. New York: Harper\&Row, 1977.

Heidegger, Martin. History of the Concept of Time: Prolegomena. Translated by Theodore Kisiel. Bloomington: Indiana University Press, 1985.

Henry, Michel. The Essence of Manifestation. Translated by Girard Etzkorn. The Hague: Martinus Nijhoff, 1973.

Husserl, Edmund. Ideas Pertaining to a Pure Phenomenology and Phenomenological Philosophy, First Book: General Introduction to a Pure Phenomenology. Translated by F. Kersten. The Hague: Martinus Nijhoff, 1982.

Kant, Immanuel. Critique of Pure Reason. Translated by Werner S. Pluhar. Indianapolis, IN: Hackett, 1996.

Merleau-Ponty, Maurice. Phenomenology of Perception. Translated by Donald A. Landes. London \& New York: Routledge, 2012.

Ricœur, Paul. “The Concept of Responsibility: An Essay in Semantic Analysis.” Translated by D. Pellauer. In The Just, 11-35. Chicago and London: The University of Chicago Press, 2000.

Romano, Claude. Event and World. Translated by Shane Mackinlay. New York: Fordham University Press, 2009.

Romano, Claude Event and Time. Translated by Stephen E. Lewis. New York: Fordham University Press, 2014.

Sartre, Jean-Paul. "Existentialism Is a Humanism." Translated by Philip Mairet. In Existentialism and Humanism, 17-54. London: Eyre Methuen Ltd., 1948.

Sartre, Jean-Paul. “Intentionality: A Fundamental Idea of Husserl's Phenomenology.” Journal of the British Society for Phenomenology 1, no. 2 (1970): 4-5.

Sartre, Jean-Paul. Being and Nothingness: A Phenomenological Essay on Ontology. Translated by Hazel E. Barnes. New York: Washington Square Press, 1992.

Sartre, Jean-Paul. Sketch for a Theory of the Emotions. Translated by Philip Mairet. London \& New York: Routledge, 2002. de Warren, Nicolas. Husserl and the Promise of Time: Subjectivity in Transcendenal Phenomenology. Cambridge: Cambridge University Press, 2009. 